\title{
Preface. \\ The IV International Scientific and Technical Conference "Gas Hydrate Technologies: Global Trends, Challenges and Horizons" (GHT 2020)
}

\author{
Hennadii Pivniak ${ }^{1}$, Iryna Kovalevska ${ }^{2}$, Roman Lysenko ${ }^{2}$, and Kateryna Sai $^{2}$ \\ ${ }^{1}$ Dnipro University of Technology, Department of Power Engineering, 19 Yavornytskoho Ave., \\ 49005 Dnipro, Ukraine \\ ${ }^{2}$ Dnipro University of Technology, Department of Mining Engineering and Education, 19 \\ Yavornytskoho Ave., 49005 Dnipro, Ukraine
}

Dear researchers, on behalf of the organizing committee, we are very pleased to welcome you and present the collection of the scientific articles of the GHT 2020 conference.

The history of conferences on gas hydrate technology in Ukraine begins in 2014. The first conference was held at the National University "Yuri Kondratyuk Poltava Polytechnic". It gave an impetus to three main directions of gas hydrate technologies: artificial production of gas hydrates, their study and development of dissociation methods; development of technologies for gas extraction from gas hydrate deposits in the Black Sea; development of technologies for obtaining gas hydrates from coal bed methane for its transportation to consumers in a compact form.

The second conference was held at the Dnipro University of Technology in 2016 and was devoted to the detailed study of the geological structure of gas hydrate deposits in the Black Sea. At this conference, Academician Yevhen Shniukov expressed the hypothesis of the renewability of gas hydrates after their decomposition and removal of gas on the surface, by feeding deep gas. Thus, the academician suggested that gas hydrate deposits of the seas and oceans should be classified as renewable energy sources. Classification of gas hydrate deposits was also presented at the conference for the number of rock inclusions and the amount of thermal energy spent on the dissociation of gas hydrates. It was discovered that the effective time of dissociation process of gas hydrate deposit of heterogeneous structure is changed by exponential dependence on the radius of its decomposition zone, which increases with a decrease in the percentage of natural inclusions.

The third conference was held in Ivano-Frankivsk National Technical University of Oil and Gas in 2018. It focused on well drilling technologies for gas extraction from gas hydrate deposits and on improving gas recovery efficiency from previously suspended wells. Another important area of the gas hydrate technologies conference was prevention of gas hydrate slugs formation in pipelines during gas transportation.

This time, at the fourth conference dedicated to gas hydrate technologies, there were a lot of interesting reports and innovative research results. The study and analysis of technically recoverable methane hydrate potential of the marine regions in the exclusive economic zones of Turkey were conducted. The method of estimation of dissociation rate of gas hydrate in porous rock bed is presented, in which by means of mathematical modeling a rational placement of wells in the gas-hydrate deposit is predicted. The results of research into phase 
transformations in reservoir systems models in the presence of thermodynamic hydrate formation inhibitors are presented. Italian National Institute of Oceanography and Applied Geophysics introduced an analytical review of the gas hydrate distribution offshore Chilean margin. Jilin University and Key Laboratory of Marine Mineral Resources of China in collaboration with Dnipro University of Technology reported about design of a microwave antenna for preventing secondary formation of gas hydrate. You can find these and many other studies in our GHT 2020 conference proceedings.

We would like to extend our appreciation to all the organizing committee members for their continuous hard work and their professional efforts in publishing this conference proceedings. We would like to express our gratitude to all participants for presenting the research results at the conference. Special acknowledgements go to EDP Sciences team.

We are looking forward to meeting you at the next GHT conference! 